implications for prevention and management. Am J Med 1993:94:313-328.

6. Ayliffe GAJ. The progressive intercontinental spread of methicillin-resistant Staphylococcus aureus. Clin Infect Dis 1997;24(suppl 1):S74-S79.

7. Boyce JM, Jackson MM, Pugliese G, Batt MD, Fleming D, Garner JS, et al. Methicillin-resistant Staphylococcus aureus: a briefing for acute care hospitals and nursing facilities. Infect Control Hosp Epidemiol 1994;15:105-115.

8. Crossley K, Landesman B, Zaske D. An outbreak of infections caused by strains of Staphylococcus aureus resistant to methicillin and aminoglycosides, II: epidemiologic studies. J Infect Dis 1979;139:280-287.

9. Duckworth GJ. Diagnosis and management of methicillin resistant Staphylococcus aureus infection. BMJ 1993;307:1049-1052.

10. Hershow RC, Khayr WF, Smith NL. A comparison of clinical virulence of nosocomially acquired methicillin-resistant and methicillin-sensitive Staphylococcus aureus infections in a university hospital. Infect Control Hosp Epidemiol 1992;13:587-593.

11. Boyce JM. Methicillin-resistant Staphylococcus aureus: detection, epidemiology and control measures. Infect Dis Clin North Am 1989;3:901 913.

12. Nicolle LE, Bialkowska-Hobrzanska H, Romance L, Harry VS, Parker S. Clonal diversity of methicillin-resistant Staphylococcus aureus in an acute care institution. Infect Control Hosp Epidemiol 1992;13:33-37.

13. Dammann TA, Wiens RM, Taylor GD. Methicillin-resistant Staphylococcus aureus: identification of a community outbreak by monitoring of hospital isolates. Can J Public Health 1988;79:312-314.

14. Romance L, Nicolle LE, Ross J, Law B. An outbreak of methicillin-resistant Staphylococcus aureus in a pediatric hospital. How it got away and how we caught it. Can J Infect Control 1991;6:11-13.

15. Taylor G, Kirkland T. Kowalewska-Grochowska K, Wang Y. A multistrain cluster of methicillin-resistant Staphylococcus aureus based in a native community. Can J Infect Dis 1990;1:121-126.

16. Laboratory for Disease Control. Methicillin-resistant Staphylococcus aureus_Canada. Canada Diseases Weekly Report 1984;10:26-28.
17. Embil J, Ramotar K, Romance L, Alfa M, Conly J, Cronk S, et al. Methicillinresistant Staphylococcus aureus in tertiary care institutions on the Canadian prairies, 1990-1992. Infect Control Hosp Epidemiol 1994;15:646-651.

18. Tokue Y, Shoji S, Satoh K, Watanabe A, Motomiya M. Comparison of a polymerase chain reaction assay and a conventional microbiologic method for detection of methicillin-resistant Staphylococcus aureus. Antimicrob Agents Chemother 1992;36:6-9.

19. Geha DJ, Uhl JR, Gustaferro CA, Persing DH. Multiplex PCR for identification of methicillin-resistant staphylococci in the clinical laboratory. $J$ Clin Microbiol 1994;32:1768-1772.

20. Tenover FC, Arbeit RD, Goering RV, Michelson PA, Murray BE, Persing $\mathrm{DH}$, et al. Interpreting chromosomal DNA restriction patterns produced by pulsed-field gel electrophoresis: criteria for bacterial strain typing. J Clin Microbiol 1995;33:2233-2239.

21. Hicks NR, Moore EP, Williams EW. Carriage and community treatment of methicillin resistant Staphylococcus aureus: what happens to colonized patients after discharge? J Hosp Infect 1991;19:17-24.

22. Mylotte JM. Control of methicillin-resistant Staphylococcus aureus: the ambivalence persists. Infect Control Hosp Epidemiol 1994;15:73-77.

23. Klimek JJ, Marsik FJ, Bartlett RC, Weir B, Shea P, Quintiliani R. Clinical, epidemiologic and bacteriologic observations of an outbreak of methicillin-resistant Staphylococcus aureus at a large community hospital. Am J Med 1976;61:340-345.

24. Lugeon C, Blanc DS, Wenger A, Francioli P. Molecular epidemiology of methicillin-resistant Staphylococcus aureus at a low-incidence hospital over a 4-year period. Infect Control Hosp Epidemiol 1995;16:260-267.

25. Hiramatsu K, Hanaki H, Ino T, Yabuta K. Oguri T, Tenover FC. Methicillin-resistant Staphylococcus aureus clinical strain with reduced vancomycin susceptibility. J Antimicrob Chemother 1997;40:135-136.

26. Centers for Disease Control and Prevention. Staphylococcus aureus with reduced susceptibility to vancomycin-United States, 1997. MMWR 1997;46:765-766.

\title{
Integrity of Latex Gloves
}

\section{Gina Pugliese, RN, MS}

Martin S. Favero, $\mathrm{PhD}$

Researchers from John Hopkins school of medicine recently conducted a study to assess the loss of integrity of the latex-glove barrier during use in the emergency department (ED) setting. A prospective observational study was conducted in an urban ED and level I trauma center. Procedures performed by ED healthcare workers (HCWs) were directly observed, timed, and categorized. The gloves used by the HCWs were collected and subjected to the standard US FDA leak test.

The results showed that $99(7.9 \%)$ of 1,254 pairs of gloves used for observed procedures leaked, compared with 2 of 200 unworn control pairs (1.0\%) and 12 of 300 pairs that were worn but not used (4.0\%). Leak rates varied by manufacturer and were higher for gloves worn 20 minutes or longer $(13.7 \%$; $P=.015)$, used for four or more procedures $(50 \% ; P<.01)$, or used for critical-care procedures $(23.5 \% ; P<.01)$. Sixty-six of an additional 325 pairs of gloves collected from unobserved critical-care procedures (20.3\%) leaked.

The researchers concluded that loss of glove integrity occurs during the performance of ED procedures, subjecting the HCW to possible infectious-fluid exposure. Risk of glove perforation increases with duration of wear, number of procedures performed, and the performance of critical-care procedures.

FROM: Hansen KN, Korniewicz DM, Hexter DA, Kornilow JR, Kelen GD. Loss of glove integrity during emergency department procedures. Ann Emerg Med 1998;31(1):65-72. 